This author accepted manuscript is deposited under a Creative Commons Attribution Non-commercial 4.0 International (CC BY-NC) licence. This means that anyone may distribute, adapt, and build upon the work for non-commercial purposes, subject to full attribution. If you wish to use this manuscript for commercial purposes, please contact permissions@emerald.com.

\title{
Factors Affecting eWOM Credibility, Information Adoption, and Purchase Intention on Generation Y: A Case from Thailand
}

\author{
Daowd, A., Hasan, R., Eldabi, T., Rafi-Ul-Shan, P. M., Cao, D. \& \\ Kasemsarn, $\mathbf{N}$.
}

Author post-print (accepted) deposited by Coventry University's Repository

Original citation \& hyperlink:

Daowd, A, Hasan, R, Eldabi, T, Rafi-Ul-Shan, PM, Cao, D \& Kasemsarn, N 2021, 'Factors

Affecting eWOM Credibility, Information Adoption, and Purchase Intention on Generation

Y: A Case from Thailand', Journal of Enterprise Information Management, vol. 34, no. 3, pp. 838-859

https://dx.doi.org/ 10.1108/JEIM-04-2019-0118

DOI 10.1108/JEIM-04-2019-0118

ISSN 1741-0398

Publisher: Emerald

Copyright $(\subset$ and Moral Rights are retained by the author(s) and/ or other copyright owners. A copy can be downloaded for personal non-commercial research or study, without prior permission or charge. This item cannot be reproduced or quoted extensively from without first obtaining permission in writing from the copyright holder(s). The content must not be changed in any way or sold commercially in any format or medium without the formal permission of the copyright holders.

This document is the author's post-print version, incorporating any revisions agreed during the peer-review process. Some differences between the published version and this version may remain and you are advised to consult the published version if you wish to cite from it. 


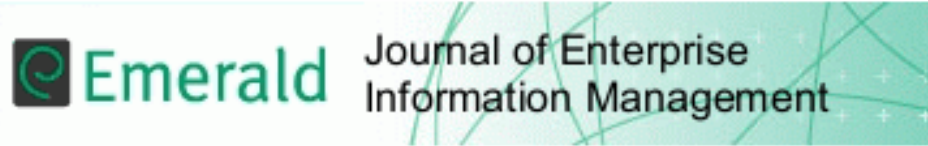

\section{Factors Affecting eWOM Credibility, Information Adoption, and Purchase Intention on Generation Y: A Case from Thailand}

\begin{tabular}{|r|l|}
\hline Journal: & Journal of Enterprise Information Management \\
\hline Manuscript ID & JEIM-04-2019-0118.R2 \\
\hline Manuscript Type: & Research Article \\
\hline Keywords: & $\begin{array}{l}\text { Electric Word of Mouth (eWOM), Purchase Intention, Consumer Reviews, } \\
\text { Social Media }\end{array}$ \\
\hline \multicolumn{2}{l}{} \\
\end{tabular}




\section{Factors Affecting eWOM Credibility, Information Adoption, and}

\section{Purchase Intention on Generation Y: A Case from Thailand}

\section{ABSTRACT}

Research aim/purpose: With the ever expanding online shopping, Electronic Word of Mouth (eWOM) has become a significant factor affecting the consumer decision making behaviour. This is specially the case when considering Generation Y (Millennials), who are old enough to be independent buyers and young to be almost immersed in online living. This article aims to assess the impact of eWOM on "purchase intention by developing a conceptual model of hypotheses encompassing a multitude of factors that may be associated with this relationship. Design/methodology/approach: The researcher investigates what factors impact eWOM credibility and make the consumer may adopt it when making a purchase. To examine our research model, a quantitative approach is employed for this purpose using a sample through online survey from Thailand - where there is a large number portion Generation Y consumer base.

Findings/Contribution/Originality: It was found that source style as a visual attribute information is the most significant factor that may impact eWOM credibility in addition to source credibility, argument quality, and source homophily, respectively. This is believed to add significant insights to the eWOM literature by identifying its route of impact toward the purchase intention on Generation Y. From a practical point of view, it helps firms to understand what needs to be taken into consideration when building their marketing strategy.

Keywords: Electric Word of Mouth (eWOM), Generation Y, Purchase Intention, eWOM adoption, eWOM credibility, Social Media, Consumer Reviews 


\section{Introduction}

Web 2.0 has transformed the interaction of information exchange, where people react to websites, upload their own data, and give comments. This development has considerably amplified the scope and scale of Electronic Word-of-mouth (eWOM) communication (Reza Jalilvand et al., 2011). eWOM is unique the medium for communication between consumers who have never met, for example, customer reviews, website blogs and comments. Recently, the eWOM has been a target outline for online marketers. This is mainly due to the fact that it is far reaching, transparent, and easy to access (Kozinets et al., 2010). Such consumergenerated information is very helpful for decision making on purchases because it provides consumers with indirect experiences on products and services.

However, the significant growth of e-WOM has raised some issues for organizations in terms of flow control of eWOM and the credibility of the sources of information. Due to the fact that eWOM is far reaching, fast transmitting, transparent, and easy to access, it has the tendency to be out of the control of firms in numerous ways. eWOM becoming important with rising trends, particularly amongst Generation Y, where more consumers are relying on eWOM sources of information and perceiving it as more credible than the shop's own marketing information. Prior to the rise of digital age, consumers shared product-related experiences only through the traditional WOM, where it was highly restricted in time and space. Today, consumers are sharing their eWOM experiences more widely and throughout many online platforms such as web blogs, customer review sites, and social media platforms (Lin et al, 2013). Given that eWOM information take place online, many firms may feel that they can leverage, and to some extent, control their flows of in order to retain the good brand images, and also learn more about their customer behaviours and insights (Bataineh, 2015).

Furthermore, the advent of eWOM started to shift the emphasis of communication from business-to-consumers towards consumers-to-consumers who are becoming the main content creators. This reduces the monopoly of information provided by organization as the main brand shaper amongst buyers. Customers tend to believe/trust more in interpersonal communications with other customers on product and services rather than the marketer-generated contents (Mangold \& Faulds, 2009). The credibility of eWOM is introduced as an extent that one perceives the recommendation from the particular source whether person/organization as a believable source of information (Fogg et al., 2002). That is, the judgment of receivers on the 
information credibility is considered as the key element in the early stage of information persuasion process (Hilligoss and Rieh, 2008). Therefore, firms need to understand the factors that contribute to the perceived credibility of eWOM and how it enhances consumer purchase intention, as well as the impact that eWOM create to the consumers. Hence, this paper aims to explore the impact of e-WOM has on generation Y purchasing decision - with particular focus on Generation $\mathrm{Y}$ - in the digital marketplace. This paper firstly investigates the reasons behind the issue of trust and credibility in online reviews and of Generation Y. Then, it will review the end-to-end online customer experience touchpoint in terms of, for example, comments about particular product or service, the reasons behind any positive or negative reviews and comments.

\section{Literature Perspective}

\subsection{Word of Mouth (WOM)}

The importance of WOM has long been the topic that is significant for people like marketers, researchers, and practitioners for decades. Traditional or offline WOM has been shown a significant role for manipulating customer purchase decisions (Richins and Root-Shaffer, 1988; Hennig-Thurau et al., 2004). According to Katz and Lazarfeld (1955), WOM is defined as a process or act of exchanging information about products and services among consumers. It plays an important role in enhancing consumers' attitudes towards the business or behaviours as the customer engage in the discussion about the market information. Due to the information overload for consumers during the product search period, they tend to believe and trust in WOM more than the marketer generated content (Chu and Kim, 2011). The reason behind this is that WOM is initiated and delivered by the users' side, showing the real experience that they have faced with the products and services unlike the marketer generated contents from the company (Feick \& Price 1987). Therefore, customers frequently rely on WOM when they search for information to justify their purchase decision.

Furthermore, Harrison and Walker (2001) stated the meaning of WOM as the one-to-one communication between a non-profit communicant in which the sender and receiver is interested in any given brand, product, or service. The importance of WOM is not only limited in terms of traditional marketing ways, it is also a crucial element that transforms the behaviours and attitudes of customer more than the traditional marketing tools like mass media and advertising (East et al., 2008). Moran and Muzellec (2017) explained that negative WOM 
can reduce the possibility of buying products, and can lead to the bad reputation of the brand. Hence, it is important for the brand and company to monitor, enhance, and contribute the positivity of WOM among their current and potential customers.

\subsection{Electronic Word-of-Mouth (eWOM)}

There are several definitions for eWOM in the literature. Whilst, most definition tend to agree on the basic construct of eWOM, each tackle it from a different angle. For example, Hennig et al. (2004) define eWOM as the positive or negative statements made by actual, former, or potential customers of a particular product or company, and that the information freely accessible online. On the other hand, Cheung et al. (2008) state that eWOM can also be considered as an extension or evolution from interpersonal communication to a new generation of cyberspace information exchange. Moreover, Chu and Kim (2009) viewed eWOM as the consumption-related or marketing information that is provided by customers or internet users in online platforms. Wang and Rodgers (2011) classified the eWOM into two contexts. The first context of eWOM is the information-oriented. This type of eWOM includes the reviews, forums, and product feedback sites that particularly focus on the product/service performances. The second context of eWOM is the emotion-oriented. This type of eWOM focuses more on the broader product experiences, which are considered to be more subjective and not necessarily included product focused online communities. Furthermore, Cheung et al. (2009) clarified that eWOM as a communication between customers and their peers, whether to endorse or disapprove of products or services that they have experienced. eWOM is classified as a truthful and trustworthy product evaluation because it balances and assesses the brand from real user experiences and perspectives.

The advent of the Internet has directly contributed to the significance of eWOM (Hennig et al., 2004). The emerging of Web 2.0 enables internet users to exchange information and experiences through the platforms like customer review sites, Web boards, Social Networking Sites (SNS) such as Facebook and Instagram, discussion boards, instant messaging applications, and other online communities (Brengarth \& Mujkic, 2016).

As more consumers are turning to the Internet to search and share for product information, it results in great volumes of consumer opinions being available online (Reichelt et al., 2014). This increasing popularity of eWOM has turned the internet to be full of the product and service information (Moran and Muzellec, 2017). Hence, it is essential for firms to spot the 
opportunities that existed in the Internet, and adapt it to their businesses. For example, Airbnb, the famous online platform for property renting and space, has implemented the eWOM to their business and found the tremendous success.

\subsection{Online Customer Review as part of eWOM}

Online Customer Review (OCR) is defined as the peer-generated evaluation of product in which posted on the company's website or the third-party agent (Mudambi and Schuff, 2010). It is considered as an important source of information and plays a crucial role to both product manufacturers and customers along with the user-generated content platforms like websites, social networking sites, and e-commerce (Somprasertsri and Lalitrojwong, 2010). The advent of OCR has led to increased customers' perception and social presence online (Kumar and Benbasat, 2006; Yoo \& Gretzel, 2008). OCR is a powerful marketing communication tool and has the potential to attract more website visits as well as increase the time that customer spends on the site, and it can be used to create a sense of community among loyal customers and frequent shoppers (Gretzel et al., 2011). Customers have implemented this information to support their purchase decision, evaluate the credibility of the sellers, and also exchange their post-experiences with the products and services online (Ladhari and Michaud, 2015). This can also be viewed as an opportunity from manufacturer perspective. Knowing the insight about desires and preferences of customer is highly treasured for the research and development, customer relationship management, and marketing department of the firm (Kumar and Benbasat, 2006). In addition, firms can further this information to enhance the shopping experience and satisfaction of customer. For example, online merchants nowadays allow customers to express their opinion on product and service through customer review section. Retail websites also offer the customers the opportunity to rate their service with the content in form of numerical star ratings (Mudambi and Schuff, 2010). Hence, OCR becomes a crucial factor that facilitates the online transactions between buyers and sellers, and unavoidably gives the tremendous impact directly on the customer purchase decision (Elwalda et al., 2016).

\subsection{Purchase Intention}

The purchase behavior of customers in the era of e-commerce has captured significant interest from researchers and practitioners in various ways (Lee and Lee, 2015). There has been an extensive effort that attempted to analyse how customers make online purchase 
because of its immediate influence on sales (Van der Heijden et al., 2003). Naturally, stimulating customers to purchase more products has been the most important target for businesses, whilst online recommendation systems play a significant role during the information search of customer. Morinez et al. (2007) along with Shah et al. (2012) defined purchase intention as a situation where customers tend to buy a certain product in particular condition. It is also a kind of a decision-making stage which indicates the reason that customers buy particular products and brands in various conditions (Kotler \& Armstrong, 2010). Purchase intention is a composite process, which usually related to the perceptions, behavior, and attitudes of consumers. In the information adoption process, purchase intention may be changed under the influence of source trustworthy and information usefulness. Thus, business need to determine the factors that lead to purchase intention of their potential customer during the online search period in order to shape them to the actual purchase.

\subsection{Generation $Y$ and their Internet Usage Behavior}

The emergence of the information age in the 1990s has had a profound effect on all aspects of life and on people at all ages. Such impact affect has an even deeper impact and transformed the behaviour of consumers who grew up in that era, which is called Generation Y (Gen Y). This generation includes people who were born in the period between 1980 and 2000 . Approximately one third of the world's population is Gen Y which is the biggest online consumer segment (with independent income) today (Valentine and Powers, 2013). According to Amornvivat et al. (2014), there are more than 2 billion of Gen Y consumers. If we take a country like Thailand, we find that Gen Y represent about $28 \%$ of the Thai population, and it is the highest among any other generations, and seems to remain the biggest for decades.

Given such a rising rate amongst other generations, businesses need to pay close attention to the rise of this Generation, not only because they represent the biggest group with high spending consumers, but also play an important role as a key influencer in online purchase. Gen Y has relatively high income compared to their young age, and high tendency to spend compared to the Gen X or Baby boomer (Panjakajornsak, 2017). Gen Y are likely to be mostly affected by the revolution of internet and social networking. Coupled with the rising affluence and the power of digital technology, it has given this generation a higher level of exposure to technology more than any of the previous generations (Amornvivat et al., 2014). The key influence on this generation is that they grew up with the Internet, which means that they 
always prefer to consume information and interact with others online instead of the traditional media (Sasmita and Suki, 2015). They exploit social media as the channel to exchange information and create identity online. It is the generation with information driven, with the one-click instant access to the world of online information shared on the social media, blogging websites, and online communities (Amornvivat, 2014). They have plenty of media choices and options available, in which could be positive for firms to target the right customer with their online offerings and drive the positive product review. However, the other side of the coin is the negative review which might damage the reputation of the firm and affect the brand image. Hence, business needs to construct eWOM strategy to draw Gen Y to associate with the positive eWOM and online sharing to their offering. With such online strategy, it is helpful for the firms to fast-track the purchase decision with the monitoring system that leads to positive review, and manage with the negative review immediately.

The above discussion stresses the importance of eWOM in shaping the opinion of consumer in general and the Gen Y in specific. This was a culmination of the introduction of web 2.0 and technology savvy Gen Y. Hence, in order to understand the significant impact of eWOM on Thai Generation Y purchase intention and understand their information adoption process, it is essential to identify the elements and applicability throughout the process of the eWOM communication in which persuade the information adoption by consumers.

\section{Hypotheses Development}

Reviewing research models considering eWOM from different angles, Teng et al., (2017) developed a model to identify critical factors that influence Chinese and Malaysian users' attitudes and behavior when processing persuasive eWOM messages. A model was also developed by Cheung et al., (2008) to examine the extent to which opinion seekers are willing to accept and adopt online consumer reviews and which factors encourage adoption. Lis (2013)'s model was designed to examine factors that influence the perceived credibility of consumer online recommendations while the model of Tien et al., (2018) focuses on the influence of $\mathrm{C} 2 \mathrm{C}$ eWOM using information persuasion in reference to purchase decision making. Therefore, this study's framework is formulated based on the information adoption model which is associated to the eWOM as from the above mentioned research models. 


\subsection{Source Credibility}

Lis (2013) stated that source credibility is the term that defines the positive characteristic of the communicator that affects the acceptance of message from receiver. Credible information sources often generate the positive and persuasive message in which convince the favourable attitude toward the products/services associated to the reviews (Eagle and Chaiken, 1993). Eagle and Chaiken (1993) adopted the source credibility model from Hovland et al. (1959) proved that source credibility has a positive effect on the attitude, opinions, and the conduct of receiver. In the same way, Park and Lee (2009) along with Wu and Wang (2011) studies have shown that source credibility is the crucial factor in defining the effectiveness of eWOM. Prior study on online credibility by Wathen and Burkell (2002) shows that credibility is the significant factor for the final recommendations in electronic consumer recommendation, as the higher credibility from information senders tend to attract receivers to follow product recommendation.

However, there is still a debate among researcher about the precision and dimension of the construct. Source credibility generally consists of two elements which are source trustworthiness and expertise of information sender (Hovland et al., 1959; Tien et al., 2018; Kim et al., 2018). The author derived source credibility from the framework of Cheung et al., (2008) and Tien et al., (2018). Perceived trustworthiness refers to the degree of confidence and acceptance that receiver developed toward the source including the extent to valid information in source communities and correlate with the consumer perceptions toward the website (Willemsen et al., 2012; Park and Lee, 2009). Consumer usually trusts the information on wellknown websites and assess it as more credible than those on unknown website. The other aspect of source credibility is the expertise of information sender referred to the professional knowledge that source communicator has towards the products/services (Wu and Wang, 2011). Consumer tends to believe information from those who have greater expertise, experience, skills, or knowledge correlate to a particular product, service, and brand.

Nevertheless, there is one factor that had not been evaluated by any model, which is the consumers' judgement of source credibility in online environment. It is essential to address the critical role of this consumers' judgement because it can affect to the source credibility as well (Teng et al, 2017). The acceptance of online reviews from information receivers also depends on the level of source credibility as it has the strong link between the attitude, judgment, and 
perception with eWOM message. People tend to enact the positive attitude towards products/services related to the level of eWOM credibility.

Likewise, many empirical evidences represent that source credibility has a positive influence on receiver's attitudes and behaviours (Petty et al., 1981; Dou et al., 2012). Cheung et al. (2008) suggested that information that was created by the credible sources will be likely to be perceived as reliable and useful, and it increases the chance of spreading this information to their communities. Conversely, consumers sometimes might not be able to distinguish the credibility of source due to the differences in product knowledge level. They simply search for the information on the internet, avoid confusion and complicated information, and save time by the reliance of informational evaluation from surrounding instead. Therefore, if consumers believe that a review has been written by an expert from the well-known website, they are more likely to expose and consider it in the positive manner, in which result to the stronger and higher purchasing decision (Teng et al, 2017). Based on the above discussion, this research first hypotheses is as follow

\section{H1: Source credibility has a positive impact on eWOM Credibility}

\subsection{Source Style}

In the context of online review, it could be in the combination of texts and visual cue that represent in the website and social networking site (SNS). Teng et al. (2014) defined source style as the visual text and visual cues that can encourage both information elaboration and retention. Kim and Lennon (2008) study shows the significant classification of online product presentation format that influences the consumer attitude and purchase intention in online shopping. The study defined visual information of a product as the photos, pictures, and videos, and proposed that visual information of product can encourage the information elaboration and increase the potential product recall tasks from consumers. Lin et al. (2012) also stated that both visual and verbal forms of online information can increase the competence of understanding and enlarging product information. Result from Lin et al. (2012) research shows that participants rated eWOM articles with visual information higher in every aspect than identical articles that presented without visual information. Furthermore, the study also stated that participants who read eWOM information of search product with pictures would develop greater product interests and purchase intention more than those without pictures (Lin et al, 2012). Moreover, Teng et al. (2017) explained that an increasing number of online reviews are 
uploaded with pictorial information and express through the mode of personal experiences and emotions in eWOM communication.

However, not only the visual attribute information is the significant factor that matters in source style, it is also important to consider the source content. Moran and Muzellec (2017) study on the $4 \mathrm{C}$ of credibility framework illustrate that 'content' of the source or eWOM message is another determinant of the eWOM credibility. Content in the model refers to message clarity and valence of communication. The clarity of online message relies on both attribute ambiguity and language abstraction (Moran and Muzellec, 2017). Attribute ambiguity is the reason why consumers hate or love the experience from brand (Gershoff et al, 2007). The eWOM is considered as credible source of information when the attribute resembles with eWOM receiver. According to Schellekens et al., (2010), the language abstraction describes a branded experience by customers whether it is concrete or abstract. The concrete language term is the recent experience and abstract language assorted with customer's lifetime experience. Message language and attributes are important factors in eWOM framework because the eWOM receiver has to decode and understand the message in the proper manner as the sender (Christiansen and Tax 2000).

In respect to the valence of online review, eWOM content is usually associated with the valence of side of the message in which could be positive or negative (Moran and Muzellec, 2017). The previous study from Cui et al., (2010) found that negative online reviews have more impact than positive ones. Yet, the same study also found that negative online reviews increased product sales. De Maeyer, (2012) explained this situation as the negative online reviews stimulate more awareness of cognitive elaboration of the product information which leads to the better understanding and are eventually converted into increased sales. Cheung et al. (2009) stated that another significant perspective of source style is recommendation sidedness. Primarily, messages are classified as one-sided information including the positive or negative statement. Meanwhile, the two-sided information includes both of the negative and positive statement. Regarding to the perceived eWOM credibility, two-sided message is more versatile as it increases quality of the review, and tends to perceived to be more credible (Cheung et al, 2009). Moreover, the framework by Teng et al., (2017) illustrate the significance of source style and include it as a major factor influencing eWOM. 
Apart from visual attribute and content, Archak et al. (2011) applied the opinion mining method using data from Amazon.com, he found that writing style and language used in review affected both perception and the following impact of those messages. King et al., (2014) also indicated that it is essential to provide more information to confirm the credibility of the review for the feature-based product, whereas the review about experimental goods such as music and movie requires more subjective points of view. Altogether, the source style including the visual information, content, writing style and language used in the review is the element that can contribute to eWOM credibility in the communication process. Building on that, our research second hypotheses is as follow:

\section{H2: Source style positively affect the eWOM Credibility}

\subsection{Argument Quality}

Argument Quality refers to the persuasive strength of argument that embedded in an informational message (Bhattacherjee and Sanford, 2006). Cheung et al. (2009) explained more that it is the level of the argument convincing that receivers consider in defending the position. The study from Sia et al. (1999) also shows that argument quality will influence the attitude of message receivers in a social media context. Especially when customers recognize that the information suit with their requirements and needs, they are willing to critique the value of the products based on their purchase criteria (Olshavsky, 1985). If the online reviews/contents are considered as a valid information from the receivers, they will establish a favourable attitude towards the products/services correlated to the reviews, and thereafter the argument quality is perceived as credible information. Contrarily, if these reviews are recognized as invalid, message receivers will establish a negative attitude towards the products/services, and eventually the argument quality is considered as not credible (Cheung et al., 2009). Hence, determining perception of consumer towards information quality on the online site is an important factor for analysing their potential purchasing behaviour.

By the same token, the framework from Delone and McLean, (2003) and Cheung et al., (2008) classify that the argument quality is often validated in four commonly used dimensions of information quality, which are relevance, timeliness, accuracy, and comprehensiveness. Petty and Cacioppo, (1986) defined relevance of the message as the extent to which reviews are relevant and applicable. As most internet users are sensible of their time, users barely read the website in detail but however scan the site quickly to find the information that they need (Madu and Madu, 2002). User wants to quickly find the information they want with less effort (Nah 
and Davis, 2002). Hence, it is important to assort only the most relevant information to display in the online community.

In addition, Timeliness refers to the current, timely, and up-to-date and information (Nelson et al., 2005). The previous research shows that when website is not updated constantly, it cannot provide the added value and expected performance to users (Madu and Madu, 2002). Furthermore, accuracy of messages refers to the correctness, reliability and validity of the information (Nelson et al., 2005). According to the media richness theory of Daft and Lengal (1986). It found the connection of the more accurate the messages, the higher perceived usefulness and credibility of the message will be. Moreover, comprehensiveness of messages refers to the understandable and informative in breadth and depth of information (Delone and McLean, 2003). Similarly, Sullivan (1999) advised that the more detailed the information is, the wider the breadth of user orientation and user categories of the website, and resulting in the more possibility of acquisition from users.

Altogether, the four elements of argument quality are recognized as the essential elements in online high-quality reviews. These are the factors that increase the usefulness, persuasion, and credibility from message recipients by online reviews. Therefore, the hypotheses concluded from the above discussion is as follow:

\section{H3: Argument quality has a significant impact on eWOM Credibility}

\subsection{Homophily}

Besides source credibility, style, and argument quality, a further factor appears as important for the assessment of credibility. Social homophily or homophily refers to the degree of similarity that individuals interact with one another in terms of demographic which are age, gender, education, occupation and the perceived attributes which are ethnicity, values, and preferences (Lazarsfeld and Merton, 1964; Rogers, 1983; Gilly et al., 1998). Individuals with the greater levels of similarity, interpersonal attraction, and trust develop the higher levels of emotional attachment (Hyun and Kim, 2014). Furthermore, the study from Katz et al., (2004) proved that individuals tend to interact with people who share similar characteristics due to the reason that they can lower the potential conflicts that might occur in the relationship by greater trust and emotional attachment. In the same way, online information seekers are likely to have a favourable attitude towards the website and information on it, if the website 
provides content and information that matches with their characteristics and interests (Kim et al., 2018). This leads to an increased in perceived homophily. Likewise, Gibbons and Gerrard (1991) stated that an information sender who is perceived as high affinity is more likely to give reason for the emotions and classified as more credible. For this reason, information exchange through WOM or eWOM communication happens more frequent among individuals with high homophily (Chu and Kim, 2011). Thus, according to the source attractiveness model by Lis (2013), it can be assumed that homophily is the significant element for the credibility in online recommendation. The research fourth hypotheses based on that is as follow:

\section{H4: Homophily has the positive impact on eWOM Credibility}

\section{5 eWOM Credibility}

Based on the above discussion, source credibility, source style, argument quality, and homophily are critical attributes that increase the acceptance and credibility of eWOM message by recipients. This paper has attempted to clarify that eWOM credibility derive from examining the four elements that proposed in research model, as it discovers the means by which credibility is generated from each of contributing elements. Teng et al. (2014) and Lis, (2013) defined eWOM credibility or the persuasive eWOM message as online recommendations in which were perceived as credible sources, delivering the descriptive power in online information acceptance. The judgement of recipient's online information credibility influences the level of confidence that they have in the information (Khong et al., 2010). To clarify, it means the more likelihood that people perceived eWOM message as credible source, the more acceptance and adoption they will give towards the online information. Sussman and Siegal (2003) also stated that there is high tendency that people who accept credible eWOM message intend to apply the information in their purchase decision process more than the unreliable ones. Petty et al. (2002) ensured this statement by modifying the experiment as when people considered the source as credible, they did not doubt, and adopted the information immediately. Previous studies from McKnight et al., (2002), Cheung et al., (2008) and Lis (2013) confirmed that the positive effects from online reviews developed the great willingness of eWOM information acceptance and adoption. Therefore, it is likely that credible eWOM message will be adopted by recipients in the eWOM communication and can be further applied to their purchase intention. Hence, this research build on the above argument and propose its fifth hypotheses as follow:

\section{H5: eWOM credibility has the positive impact on eWOM Adoption}




\section{6 eWOM Adoption and Purchase Intention}

Building eWOM credibility is not the only factor that contributes to the successful eWOM communication process, eWOM adoption is also playing an important role throughout the process from the credibility to purchase intention. Based on the study of Tien et al. (2018), eWOM adoption acts a mediating role in determining and connecting impact of eWOM credibility and purchase intention among consumers. McKnight and Kacmar (2006) also stated that the fundamental requirement for eWOM adoption is the credibility. According to Sussman and Siegal (2003), eWOM adoption refers to the acceptance of the recommendation of the compatible review. Also, there is high tendency that people who accept credible eWOM message attempt to utilize the information on their actual purchase decision stage.

Cheung et al., (2018) stated that eWOM adoption is derived from information adoption process which is the degree that people engage in utilizing information. Adoption is also one of the essential activities that users attempt to conduct in online virtual communities. One example provided by Pitta and Fowler (2005) is that it can be seen when consumers are searching and scanning for comments and opinions they believe it is credible which posted by others prior they actually make a purchase decision. Then, recipients are more willing to adapt a recommendation from a reliable source more than one which considered as unreliable (Bansal and Voyer 2000). eWOM credibility coupled with adoption enable consumers to determine and modify their attitudes with the purchase decisions (Park and Lee, 2009).

Previous research also revealed that trust is also the fundamental factor for eWOM adoption in the online shopping context (Lu et al., 2010). The more likelihood that a person trusts an electronic vendor, the more tendency he has to make a purchase. According to Erkan and Evans (2016), eWOM adoption can benefit electronic vendors by converting the recommendations on social networking sites into purchases. The study from Dabholkar and Sheng (2012) and Gunawan and Huarng (2015) claimed that consumer purchase intention will be increased when there is a greater trust in online recommendation agent, and also from the viral messages with the greater level of perceived usefulness and adoption. Therefore, purchase intention of consumers are literally enhanced by the eWOM credibility and trust through the beneficial influence of eWOM adoption. As from that, our last hypotheses is as follow:

\section{H6: eWOM adoption has a strong impact on Purchase Intention}




\subsection{Conceptual framework}

As from the above discussion, a conceptual framework was developed for analysing the impact of e-WOM on Generation Y Purchasing intention in Thailand as shown in Figure 1.

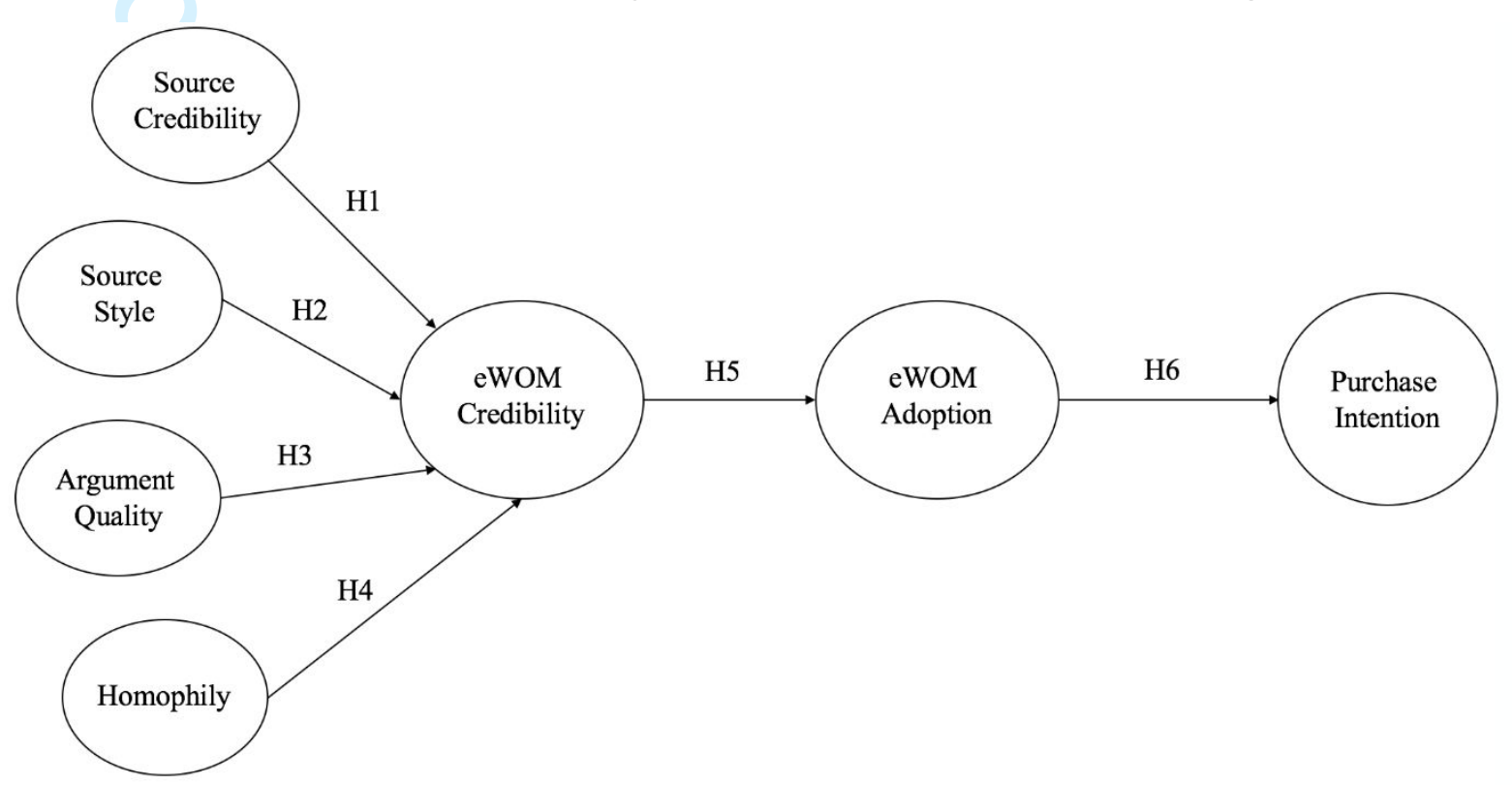

Figure 1: Proposed Research Framework

\section{Research Methodology}

As this research tries to discover the relationships among variables from eWOM to the purchase intention of customer by formulating and testing the hypotheses, quantitative research approach is the proper method where it can determine the relationship between the constructs and provide empirical evidence answering our research question. In addition, the deductive approach will be implemented in this study in order to analyse all data derived from quantitative research method. Deductive approach will also be used to test the consistency of data with former assumptions and hypotheses that identified by the researcher. Furthermore, literature provides evidences that survey questionnaire is the useful method in which can investigate the insight of participants and discover the correlation between factors (Kim et al., 2018; Tien et al, 2018; Erkan and Evans, 2016; and Reza Jalilvand and Samiei, 2012). It is also used to discover the relation among variables such as source credibility, source style, argument quality, eWOM credibility, and purchase intention towards generation $\mathrm{Y}$ in Thailand. Hence, the questionnaire survey is chosen in order to examine and test the hypotheses of this study. 
The population of this research is Thai Generation Y between 24 to 38 years old in both male and female and have experiences in online WOM such as customer reviews, blogs, web board, social media posts before making purchase to product and service. According to "We Are Social" (2018), out of overall 69.1 million of Thai population in 2017, there are 57 million people which is accounted for $82 \%$ of the population has accessed to internet. Also, 54.6 million people are the active mobile internet users in which are accounted for $79 \%$ of the overall population. Majority of them used internet on a daily basis for browsing information online. In addition, "We Are Social" (2018) illustrated that search engine websites like Google, the most visited website in which there are about billion monthly traffic, followed by Facebook, YouTube, and Pantip (local customer website and discussion forum). Furthermore, this research will utilise a non-probability sampling with the combination of purposive and snowball sampling technique. The questionnaire was conducted through Google survey in both English and Thai language as the boundaries of this study is among Thai people. All the questions were compulsory in order to avoid any missing values. All measurement items were adopted from related literature where the items' reliability was previously tested (Chu \& Kim, 2011; Norman \& Russell, 2006; Wixom and Todd, 2005; Citrin, 2001; Brown \& Reingen, 1987; Wu and Shaffer, 1987; Wiener and Mowen, 1986)

All of the question in this section is provided with Likert scale between 1 (strongly disagree) to 5 (strongly agree). The purpose of implemented this Likert scale is to allow participants to reveal their true weight of their opinion toward to subject of study. This research benefited from the advantages of small-scale version before running the extensive study (Van and Hundley, 2001). It gave the authors an indicator on to what extent the proposed methods are suitable. For this reason, this study implemented the pilot study of 20 participants before the official questionnaire was carried out. After improving the questionnaire, 230 valid responses were collected and used for the analysis phase. SPSS 25.0 software is used to analyse collected data.

\section{Results and Analysis}

\subsection{Demographic Statistics}

The total of 230 responses were employed for the analysis phase. Out of that, we found 56 percent of them were male, 60.7 percent of them are from the age range of 24-29 years old. 
The majority of participants in this research has a minimum of bachelor degree. Approximately 47 percent of participants has the master degree, and only 3.9 percent got the diplomat or below bachelor degree. Likewise, the social status of participant is illustrated below due to the factor that each category has different purchasing habits. In term of their monthly income, there are 26.5 percent of participant who has income from 25,001 to 35,000 THB, follow by 24.3 percent who got average 35,001 to $50,000 \mathrm{THB}$, couple with 23.5 percent who has 15,001 to 25,000 THB. The rest of income distributions are 20 percent of participant who has more than 50,000 THB and 5.7 percent who got less than 15,000 THB per month.

\subsection{User Background Information}

The result of our survey illustrate that all of the respondents have read and experienced with eWOM including online customer review, blogs, web board, and social media posts before they actually make a purchase. Moreover, majority of responses confirmed that Facebook is the most visited platform for this purpose with 164 participants followed by 138 for Web board, 129 answers for Customer review site. The lowest attention was given to Instagram with 88 responses. Also, the frequency of time that respondent usually read online review before make a purchase to certain product/service was questioned. 42.2 percent of the participants confirmed that they read online review before make a purchase to certain product/service 3 to 4 times, 24.8 percent stated that they read only 1 to 2 times before, 20 percent indicate that they read up to 5 or 6 times, and the rest 13 percent of respondents read more than 6 times before they make a purchase decision. Specifically, the average time that respondents spend on reading eWOM and online review is varied. 33.5 percent of respondents read quite a few from 1 to 15 minutes, 25.7 percent of them read 15 to 30 minutes, 16.5 percent read up to 30 to 45 minutes, 12.6 percent read from 45 to 60 minutes, and respectively 11.7 percent of respondents spend more than one hours reading online review and eWOM.

Likewise, the responses provided more details on the reasons why respondents choose to read online review rather than other type of sources. The most common answer is "variety of information that they can find on the internet" with frequency of 171, followed by 146 answers that choose convenience and easy to access to the online information. Credibility is also the concern as 105 answers represent the significant of the terms, along with the accuracy and precision of information that there are 80 answers show it the least important. 


\subsection{Reliability Analysis}

To ensure the quality of the measurement, the reliability test is conducted in order to examine the internal consistency of responses among group of questions incorporate in this questionnaire survey (Saunders et al., 2009), Cronbach's alpha is used for this purpose. Generally, the value should lie between 0.00 and 1.00. Bryman and Bell (2011) suggest that Cronbach's Alpha link the questions from each factor as it will be increased when the question is removed. The results show acceptable level of reliability as Cronbach's alpha is higher than the value of 0.7 (Sekaran, 2000)

\begin{tabular}{|c|c|c|}
\hline & No. of Questions & Cronbach's Alpha \\
\hline Source Credibility & 4 & 0.740 \\
\hline Source Style & 4 & 0.766 \\
\hline Source Homophily & 3 & 0.727 \\
\hline Argument Quality & 4 & 0.798 \\
\hline Information Adoption & 2 & $\mathbf{0 . 7 4 2}$ \\
\hline Purchase Intention & 2 & $\mathbf{0 . 7 5 6}$ \\
\hline
\end{tabular}

Table 1: Reliability Analysis with Cronbach's Alpha

Hair et al., (1998) claims that the reliability or Cronbach's alpha that is the lowest acceptable point is 0.6 , and the value that is higher than 0.8 indicates that all of the elements have a strong coherence. Hence, the results of the current study show acceptable level of reliability for all our constructs (as shown in Table 1).

\subsection{Factor Analysis}

Factor Analysis is a method that implemented to this study in order to identify the factors communalities, loadings. The factor analysis identifies the expected question suggested by previous theories. Furthermore, factor analysis predicts and identifies the number of factors. According to Table 2, the communalities values are illustrated and sorted by each question in the construct. Additionally, Kaiser-Meyer-Olkin (KMO) value is $0.925>0.7$ indicating that the factors between constructs in this study has high significant level. 


\begin{tabular}{|c|c|c|}
\hline & Construct & Communalities \\
\hline \multirow{3}{*}{ Source } & SC1 & .598 \\
Credibility & SC2 & .563 \\
& SC3 & .586 \\
Source Style & SC4 & .549 \\
& SS1 & .649 \\
& SS2 & .571 \\
\hline Source & SS3 & .399 \\
Homophily & SS4 & .434 \\
& SH1 & .711 \\
& SH2 & .702 \\
Argument & SH3 & .593 \\
\hline Quality & AQ1 & .589 \\
& AQ2 & .673 \\
\hline Information & AQ3 & .628 \\
Adoption & AQ4 & .572 \\
\hline Purchase & PA1 & .776 \\
Intention & PA2 & .754 \\
\hline
\end{tabular}

Table 2: The Communalities Table from Factor Analysis

\subsection{Hypothesis Testing}

This research investigates not only the relationship between variable but also determines the significant contribution of each element. Thus, both of multiple and single regression analysis are implemented in this study for better comprehension to the cause and effect connection between various variables (dependent and independent). The results indicate the level of predictive variable that affect the change in dependent variable, as well as evaluating outcome from the contribution of each predictor's element. Hence, multiple regression and single 
analysis is executed in this study in order to measure the effect of each construct such as source credibility, source style, source homophily, and argument quality, that can contribute to the overall credibility of eWOM and affect information adoption and purchase intention. Figure 2 represents the hypotheses testing results for both multiple and single regression analysis to measure different factors in eWOM area that impact the purchase intention of Generation Y. The results of this analysis confirm that standardized coefficient beta and $\mathrm{R}^{2}$ are all significant values. As a result, eWOM credibility is significantly impacted in a positive relation with source credibility, source style, argument quality, and source homophily.

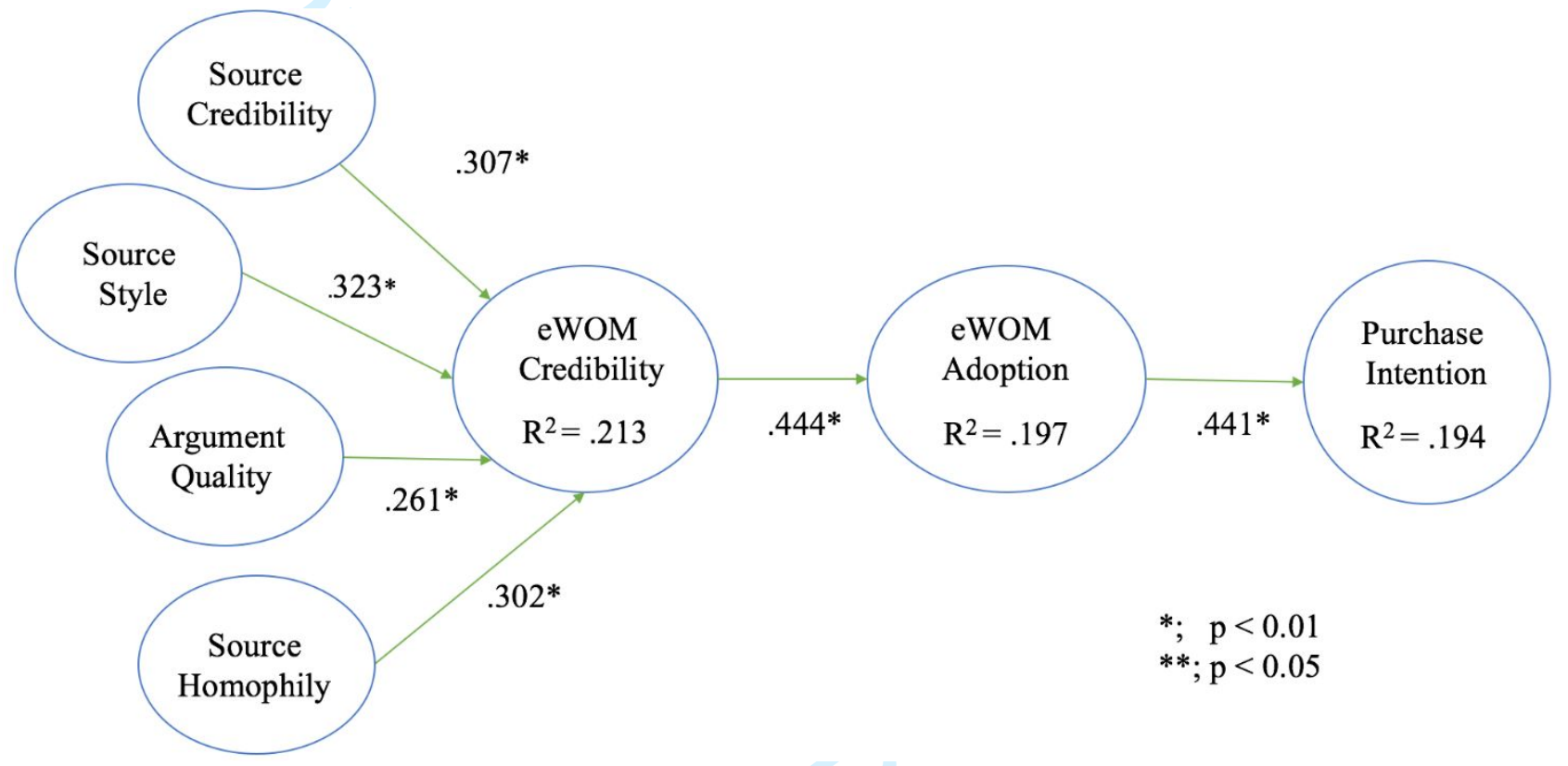

Figure 2: The Hypotheses Testing Result

The beta coefficient value for these values were $\beta=0.307 ;(p<0.01), \beta=0.323 ;(p<0.01), \beta$ $=0.261 ;(\mathrm{p}<0.01)$, and $\beta=0.302 ;(\mathrm{p}<0.01)$ respectively. The highest impact comes from source style, followed by source credibility, source homophily, and argument quality. Moreover, the eWOM credibility is also significantly related to eWOM information adoption and represents the coefficient value of $\beta=0.444$; $(p<0.01)$. In term of the impact of eWOM information adoption on purchase intention, it is also found significant with coefficient $\beta=$ $0.441(\mathrm{p}<0.01)$.

\section{Discussion}

Hypotheses formulated in this study were all accepted from the multiple and single regression analysis. The impact of eWOM on purchase intention of customer has long been under a great of attention (Filieri et al, 2018; Tien et al, 2018; Erkan and Evans, 2016; Reza Jalivand 
and Samiei, 2012; Kumar and Benbasat, 2006). Indeed, the influence of eWOM has been verified by various factors such as $4 \mathrm{C}$ of credibility framework from Moran and Muzellec (2017), customer value and eWOM framework by Nusair et al. (2017) and the eWOM effect framework from Park and Lee (2009). However, this study explains the determinants that affect the eWOM credibility which leads to information acceptance and influences customers' purchase intention.

The outcome of our empirical investigation provides an evidence that source credibility significantly affects the eWOM credibility, information adoption, and subsequently purchase intention. This evidence is consistent with Park and Lee (2009) along with Wu and Wang (2011) who confirmed that source credibility has a positive impact on overall credibility of online source, and customers tend to adapt the credible source more than the one they found unreliable. This study found that Generation Y consumer in Thailand tend to believe in expertise and professional information sender, and give the priority on the popularity of online review and eWOM. This, however, contradicts with the findings of Cheung et al., (2008) who determined that source credibility has no significant impact over information credibility and usefulness in the context of online information adoption. Cheung et al., (2008) claimed that it is somehow difficult to recognize the real identity of online users as any user can freely register and post comments/reviews without individual signature or real authorization check. Hence, readers or information receivers do not have enough indication of who is the content generator, which leads to the insignificant of source credibility.

Furthermore, the current research found that source style has the highest impact on eWOM credibility in online information adoption and consumers' purchase intention. The results indicate that Thai Generation Y consumer tend to like the detailed online review with visual information such as photos and videos. They also give an interesting aspect that website attribute in the eWOM communication influence the trustworthy and overall credibility of that site. Likewise, Teng et al. (2017) and Lin et al. (2012) found that there is a strong linkage between source style and behavioral intention of consumers. Teng et al. (2017) discovered that users are likely to believe in the contrasting online reviews and comments more than the one that has only positive or negative side.

The findings further indicated that there was statistically significant relationship of argument quality and source homophily with eWOM information adoption and purchase intention. The 
study also found that up-to-date, accurate, and relevant information are a big concern for Thai Generation Y people, and it impacts the overall credibility of that review. As same as the findings from Cheung et al. (2008) explained that online information receivers want to quickly access the information they want with less effort, as they are sensible of their time. In addition, our empirical examination demonstrates that Thai Generation Y people tend to be open-minded and accept the information that comes from a reviewer with similar characteristic, attitude, and behavior. This agrees with Kim et al. (2018) that perceptual homophily impact the purchase intention as consumers may favor the online review with viewpoints, preferences, and experiences that are the same to theirs which considered to be more persuasive than dissimilar ones. However, the result contradicts with Filieri et al. (2018) who tested the source homophily element and found it is not significant. They claim that online user focus more on the content of a review in terms of expertise and popularity of reviewer rather than examining the level of similarity that reviewer share with them.

Finally, similar to the claim of McKnight and Kacmar (2006), the result revealed that eWOM information adoption and purchase intention is the consequence. McKnight and Kacmar (2006) stated that the minimum requirement for online information adoption is the credibility that people perceived from the source. The information adoption act as the mediating role to connect the credibility to purchase intention. This claim was also supported by Gunawan and Huarng (2015) when they found that people tend to adopt online review and information when they have trust and perceived that eWOM is reliable, which result in further stage of decision making process that the purchase intention will be increased.

\section{Theoretical Contribution and Marketing Implication}

This study adds to the current body of literature on few levels. With the increased attention to eWOM for both researcher and practitioners, this research investigated new factors affecting eWOM credibility highlighting the source style as a major influencer of this credibility. The model developed in this research provide a roadmap for the purchase intention through eWOM stressing the importance of eWOM credibility as an introduction to the customer to adopt it when making purchase for a product or service. More interesting, this research considered a specific generation and age groups to study their purchasing behaviour. It provides a practical evidence that the customer decision making behaviour is varied among different generations. The Thai context also added another flavor into it. 
Moreover, the results of this research represent factors that lead to purchase intention of Thai Generation Y through the elements in eWOM communication. Thus, this research could help companies that want to plan their online marketing campaign and strategy. To point out, consumer perceived that source style is the most important factor in overall eWOM credibility. With this in mind, company should pay more attention on this element in order to attract customers to visit their website or review. For instance, the owner may add more visual information, adjust their website attribute, or make sure that there are both positive and negative comments/reviews as consumers tend to believe the review that has both side of information more than the one that has only positive side. Moreover, an insight from this study shows that consumers also give a priority to source credibility. For example, consumers tend to trust review from expert and professional, and perceived that amount of information is the main determinant for the overall credibility of online review. Hence, company should encourage the current customers to share their real experiences with the product/service, and involve the influencer or reviewer that has an expertise in order to draw the consumers' attention.

\section{Conclusion, Limitations and Future Research}

All in all, e-WOM is a powerful communication that could enhance user's experience towards product and service in many different dimensions. This research is an attempt to determine the factors that impact purchasing intention in online eWOM environment. This study revealed that Thai Generation Y people usually adapt online review as one of the key mediator that influence their purchase decision. There are 230 data collected from the online channel and analyze by implementing multiple regression analysis. The result assures that credibility of eWOM has a significant impact on consumer purchasing intention. The element that has the highest impact is source style which entirely contribute to the effectiveness of eWOM while argument quality has less impact. These four elements thoroughly perform different roles in determining the online review credibility. However, generating eWOM credibility is not the only factor that contribute to the success in online communication process, the information adoption also plays a significant role that connects the credibility to the behavioral intention. The information adoption will occur when customer perceived that source is credible. Altogether, eWOM credibility coupled with adoption determine consumers' attitude with purchase intention. 
Due to the time and budget constraints, this research can reach through only small number of respondents which lead to the unstable results and may be difficult to generalise. Moreover, the scope of this study comes from the behavior of Generation $\mathrm{Y}$ in Thailand so the result might be diverse from other countries due to the socio-cultural environment is different. However, the difference in environment can offer opportunities for future research by considering other contexts and conduct the cross-cultural research for finding the difference between cultural and behavioral intention in regard to eWOM credibility of online users. Also, the future research could apply the versatility of other factors that can lead to the credibility of eWOM message such as source perception, willingness to further share knowledge from information receiver, and the need of information in different purchasing situation. 


\section{Bibliography}

ACNielsen (2007), Trust in Advertising: A Global Nielsen Consumer Report, October, ACNielsen, New York, NY.

Amaratunga, D., Baldry, D., Sarshar, M. and Newton, R. (2002). Quantitative and Qualitative Research in the Built Environment Application of "mixed" Research Approach. Work Study, 51(1), pp. 17-31.

Amornvivat, S., Homchampa, T., Poudpongpaiboon, S., Ratanapinyowong, T., Mintarkhin, N., Arakvichanun, N., (2014). Capturing Thai Gen Y consumers - Insight. Economic Intelligence Center.

Amornvivat, S., (2014). Connecting with Thai Gen Y consumers [WWW Document]. https:/www.bangkokpost.com/opinion/opinion/444156/connecting-with-thai-gen-yconsumers.

Anderson, J. D. (2006) Qualitative and quantitative research. Imperial COE, 3.

Archak, N., Ghose, A., Ipeirotis, P.G., (2011). Deriving the Pricing Power of Product Features by Mining Consumer Reviews. Management Science 57, 1485-1509. https://doi.org/10.1287/mnsc. 1110.1370

Bansal, H.S., Voyer, P.A. (2000) Word-of-mouth processes within a services purchase decision context. Journal of Service Research 3(2):166-177

Bataineh, A.Q., (2015). The Impact of Perceived e-WOM on Purchase Intention: The Mediating Role of Corporate Image. International Journal of Marketing Studies 7. https://doi.org/10.5539/ijms.v7n1p126

B. Valentine, D., L. Powers, T., (2013). Generation Y values and lifestyle segments. Journal of Consumer Marketing 30, 597-606. https://doi.org/10.1108/JCM-07-2013-0650

Bhattacherjee A, Sanford C. (2006). Influence processes for information technology acceptance: an elaboration likelihood model. MIS Q. 30:805-825.

Biernacki, P., and Waldorf, D. (1981) 'Snowball sampling: Problems and techniques of chain referral sampling', Sociological Methods and Research, 10, pp.141-163. 
Blumberg, B., Cooper, D. and Schindler, P. (2014). Business research methods. London: McGrawHill Education

Brengarth, L. B., \& Mujkic, E. (2016). WEB 2.0: How social media applications leverage nonprofit responses during a wildfire crisis. Computers in Human Behavior, 54, 589-596.

Bryman, A. and Bell, E. (2011) Business research methods. Alan Bryman, Emma Bell. 3rd edn. New York, NY: Oxford University Press.

Chatterjee, P. (2001), “Online reviews: do consumers use them?”, Advances in Consumer Research, Vol. 28 No. 1, pp. 129-33.

Chu, S.-C., Kim, Y., (2011). Determinants of consumer engagement in electronic word-of-mouth (eWOM) in social networking sites. International Journal of Advertising 30, 47-75. https://doi.org/10.2501/IJA-30-1-047-075

Cheung, M.Y., Luo, C., Sia, C.L., Chen, H., (2009). Credibility of Electronic Word-of-Mouth: Informational and Normative Determinants of On-line Consumer Recommendations. International Journal of Electronic Commerce 13, 9-38. https://doi.org/10.2753/JEC10864415130402

Cheung, C.M.K., Lee, M.K.O., Rabjohn, N., (2008). The impact of electronic word-of-mouth: The adoption of online opinions in online customer communities. Internet Research 18, 229-247. https://doi.org/10.1108/10662240810883290

Cohen, J., Cohen, P., West, S. G., and Aiken, L. S. (2013) Applied multiple regression/correlation analysis for the behavioral sciences. Routledge.

Collis, J., Hussey, R., (2009). Business Research: A Practical Guide for Undergraduate and Postgraduate Students. Palgrave Macmillan.

Christiansen, T., and S. S. Tax. (2000). "Measuring Word of Mouth: The Questions of Who and When?” Journal of Marketing Communications 6 (3): 185-199.

Creswell, J. (2009). Research Design: Qualitative, Quantitative, and Mixed Methods Approaches. 3rd ed. Thousand Oaks, California: SAGE Publications, Inc.

Cui, P., Lui, H. and Guo, X. (2010), “Online reviews as a driver of new product sales”, Proceedings of the Fourth International Conference on Management of e-Commerce and e-Government, Chengdu, IEEE Computer Society, Los Alamitos, CA, pp. 20-25.

Daft, R.L. and Lengel, R.H. (1986), “Organizational information requirement, media richness and structural design”, Management Science, Vol. 32 No. 5, pp. 554-71.

Daugherty, T., Hoffman, E., (2014). eWOM and the importance of capturing consumer attention within social media. Journal of Marketing Communications 20, 82-102. https://doi.org/10.1080/13527266.2013.797764 
De Maeyer, P. (2012), "Impact of online consumer reviews on sales and price strategies: a review and directions for future research", Journal of Product and Brand Management, Vol. 21 No. 2, pp. 132-139.

Delone, W.H. and McLean, E.R. (2003), “The DeLone and McLean model of information systems success: a ten-year update”, Journal of Management Information Systems, Vol. 19 No. 4, pp. 9-30.

Douglas, E. P., Borrego, M., and Amelink, C. T. (2009) 'Quantitative, qualitative, and mixed research methods in engineering education',Journal of Engineering Education, 98(1), pp.5366.

Dou, X., Walden, J.A., Lee, S., Lee, J.Y., (2012). Does source matter? Examining source effects in online product reviews. Computers in Human Behavior 28, 1555-1563. https://doi.org/10.1016/j.chb.2012.03.015

Eagly AH, Chaiken S. (1993). The Psychology of Attitudes. Fort Worth: Harcourt Brace Jovanovich College Publishers.

East, R., Hammond, K., Lomax, W., (2008). Measuring the impact of positive and negative word of mouth on brand purchase probability. International Journal of Research in Marketing 25, 215-224. https://doi.org/10.1016/j.ijresmar.2008.04.001

Eberhardt, L. L. (1970) 'Correlation, regression, and density dependence',Ecology, pp.306-310.

Elo, S. and Kyngäs, H. (2008). The qualitative content analysis process. Journal of Advanced Nursing, 62(1), pp.107-115.

Elwalda, A., Lü, K., Ali, M., (2016). Perceived derived attributes of online customer reviews. Computers in Human Behavior 56, 306-319. https://doi.org/10.1016/j.chb.2015.11.051

Eriksson, P., and Kovalainen, A. (2008) Qualitative methods in business research. Sage.

Erkan, I., Evans, C., 2016. The influence of eWOM in social media on consumers' purchase intentions: An extended approach to information adoption. Computers in Human Behavior 61, 47-55. https://doi.org/10.1016/j.chb.2016.03.003

Feick, L.F. \& Price, L.L. (1987) The market maven: a diffuser of marketplace information. Journal of Marketing, 51(1), pp. 83-97.

Filieri, R., McLeay, F., Tsui, B., Lin, Z., (2018). Consumer perceptions of information helpfulness and determinants of purchase intention in online consumer reviews of services. Information $\&$ Management. https://doi.org/10.1016/j.im.2018.04.010

Fogg, B. J., Kameda, T., Boyd, J., Marshall, J., Sethi, R., Sockol, M., \& Trowbridge, T. (2002). Stanford Makovsky Web Credibility Study 2002: Investigating What Makes Web Sites 
Credible Today. A Research Report by the Stanford Persuasive Technology Lab \& Makovsky \& Company, Stanford University. Retrieved from www.webcredibility.org

Gershoff, A. D., A. Mukherjee, and A. Mukhopadhyay. (2007). "Few Ways to Love, but Many Ways to Hate: Attribute Ambiguity and the Positivity Effect in Agent Evaluation.” Journal of Consumer Research 33: 499- 505

Gibbons, FX., Gerrard, M. (1991) Downward comparison and coping with threat. In: Suls J, Wills TA (eds) Social comparison: contemporary theory and research. Lawrence Erlbaum, Hillsdale, pp 317-345

Gilly, MC. Graham, JL. Wolfinbarger, MF. (1998) A dyadic study of interpersonal information search. Academy of Marketing Science 26(2):83-100

Gretzel, U., Fesenmaier, D., Lee, Y.J., Tussyadiah, I., (2011). Narrating travel experiences: The role of new media. Faculty of Commerce - Papers (Archive) 171-182.

Guarte, J.M., Barrios, E.B., (2006). Estimation Under Purposive Sampling. Communications in Statistics - Simulation and Computation 35, 277-284. https://doi.org/10.1080/03610910600591610

Gunawan, D.D., Huarng, K.-H., (2015). Viral effects of social network and media on consumers' purchase intention. Journal of Business Research 68, 2237-2241. https://doi.org/10.1016/j.jbusres.2015.06.004

Hair, J.F., Jr, Anderson, R.E., Tatham, R.L. and Black, W.C. (1998) Multivariate Data Analysis, 5th ed., Prentice-Hall Inc., Upper Saddle River.

Harrison-Walker, L. (2001). The Measurement of Word-of-Mouth Communication and an Investigation of Service Quality and Customer Commitment As Potential Antecedents. Journal of Service Research, 4(1), pp.60-75.

Hennig-Thurau, T., Walsh, G., (2003). Electronic Word-of-Mouth: Motives for and Consequences of Reading Customer Articulations on the Internet. International Journal of Electronic Commerce 8, 51-74.

Hennig-Thurau, T., Gwinner, K.P., Walsh, G., Gremler, D.D., (2004). Electronic word-of-mouth via consumer-opinion platforms: What motivates consumers to articulate themselves on the Internet? Journal of Interactive Marketing 18, 38-52. https://doi.org/10.1002/dir.10073

Hilligoss, B., \& Rieh, S. Y. (2008). Developing a unifying framework of credibility assessment: Construct, heuristics, and interaction in context. Information Processing and Management, 44(4), 1467-1484. http://dx.doi.org/10.1016/j.ipm.2007.10.001 
Hoffman, D.L., Novak, T.P., (1997). A New Marketing paradigm for Electronic Commerce. The Information Society 13, 43-54.

Hovland, C.I., Janis, I.L., Kelley, H.H., (1953). Communication and persuasion; psychological studies of opinion change, Communication and persuasion; psychological studies of opinion change. Yale University Press, New Haven, CT, US.

Hyun, S.S., Kim, I. (2014). Identifying Optimal Rapport-Building Behaviors In Inducing Patrons' Emotional Attachment In Luxury Restaurants. Journal of Hospitality \& Tourism Research 38, 162-198. https://doi.org/10.1177/1096348012451458

Jalilvand, M. R., Esfahani, S. S., \& Samiei, N. (2011). Electronic word-ofmouth: Challenges and opportunities. Procedia Computer Science, 3, $42-46$.

Johanson, G. and Brooks, G. (2009). Initial Scale Development: Sample Size for Pilot Studies. Educational and Psychological Measurement, 70(3), pp.394-400.

Kaplan, B., and Duchon, D. (1988) 'Combining qualitative and quantitative methods in information systems research: a case study', MIS quarterly, pp.571-586.

Katz, E., Lazarsfeld, P.F., (1955). Personal influence: the part played by people in the flow of mass communications, Personal influence: the part played by people in the flow of mass communications. Free Press, New York, NY, US.

Katz, N., Lazer, D., Arrow, H., Contractor, N. (2004). Network Theory and Small Groups. Small Group Research 35, 307-332. https://doi.org/10.1177/1046496404264941

Khong, K.W., Theresa, J. and Leong, W.S. (2010), “Online advertising: a study on Malaysian consumers", International Journal of Business and Information, Vol. 5 No. 2, pp. 111-134.

King, R.A., Racherla, P., Bush, V.D., (2014). What We Know and Don't Know About Online Wordof-Mouth: A Review and Synthesis of the Literature. Journal of Interactive Marketing 28, 167183. https://doi.org/10.1016/j.intmar.2014.02.001

Kim M., Lennon S., (2008). The effects of visual and verbal informa- tion on attitudes and purchase intentions in internet shopping. Psychol Marketing 25:146-178.

Kim, S., Kandampully, J., Bilgihan, A., (2018). The influence of eWOM communications: An application of online social network framework. Computers in Human Behavior 80, 243-254. https://doi.org/10.1016/j.chb.2017.11.015

Kothari, C. R. (2011) Research methodology: methods and techniques. New Age International.

Kotler P. and Armstrong G. (2010), "Principles of Marketing”, New Jersey: Pearson Prentice Hall. Kruger, D.J. (2003) Integrating quantitative and qualitative methods in community Research, The Community Psychologist, 36, pp.18-19. 
Kumar, N., Benbasat, I. (2006). "The Influence of Recommendations on Consumer Reviews on Evaluations of Websites," Information Systems Research (17:4), pp. 425-439.

Kozinets, R., de Valck, K., Wojnicki, A., \& Wilner, S. (2010). Networked Narratives: Understanding Word-of-Mouth Marketing in Online Communities. Journal of Marketing, 74(2), 71-89.

Ladhari, R. and Michaud, M. (2015). eWOM effects on hotel booking intentions, attitudes, trust, and website perceptions. International Journal of Hospitality Management, 46, pp.36- 45.

Lazarsfeld PF, Merton RK (1964) Friendship as social process. A substantive and methodological analysis. In: Berger M, Abel T, Page $\mathrm{CH}$ (eds) Freedom and control in modern society. Octagon, New York, pp 18-66

Lee, A. (1994) 'Electronic Mail as a Medium for Rich Communication: An Empirical Investigation Using Hermeneutic Interpretation', MIS Quarterly 18(2), pp. 143-157.

Lin, C., Wu, Y., \& Chen, J. (2013). Electronic Word-Of-Mouth: The Moderating Roles Of Product Involvement And Brand Image. Proceedings of 2013 international conference on technology innovation and industrial management, Phuket, Thailand.

Lin, T.M.., Lu, K., Wu, J., (2012). The effects of visual information in eWOM communication. Journal of Research in Interactive Marketing 6, 7-26. https://doi.org/10.1108/17505931211241341

Lis, B., (2013). In eWOM We Trust: A Framework of Factors that Determine the eWOM Credibility. Business \& Information Systems Engineering 5, 129-140. https://doi.org/10.1007/s12599-013-0261-9

Lu, Y., Zhao, L., Wang, B., (2010). From virtual community members to C2C e-commerce buyers: Trust in virtual communities and its effect on consumers' purchase intention. Electronic Commerce Research and Applications 346-360. https://doi.org/10.1016/j.elerap.2009.07.003

Madu, C.N. and Madu, A.A. (2002), “Dimensions of e-quality”, International Journal of Quality and Reliability Management, Vol. 19 No. 3, pp. 246-58.

Mangold, W. G., \& Faulds, D. J. (2009). Social media: the new hybrid element of the promotion mix. Business Horizons, 52(4), 357-365. http://dx.doi.org/10.1016/j.bushor.2009.03.002

Maanen, V. (1979) 'Reclaiming Qualitative Methods for Organizational Research: A Preface', AdministrativeScience Quarterly 24(4), pp. 520-526.

McKnight, D.H., Choudhury, V. and Kacmar, C. (2002), "The impact of initial consumer trust on intentions to transact with a web site: a trust building model”, Journal of Strategic Information Systems, Vol. 11 No. 3, pp. 297-323. 
McKnight, D.H., Kacmar, C. (2006) Factors of information credibility for an Internet advice site.

In: Proc. 39th Hawaii international conference on system sciences, Hawaii, pp 1-10

Moran, G., Muzellec, L., (2017). eWOM credibility on social networking sites: A framework. Journal of Marketing Communications 23, 149-161. https://doi.org/10.1080/13527266.2014.969756

Mudambi, S.M., Schuff, D., (2010). What Makes a Helpful Online Review? A Study of Customer Reviews on Amazon.com. MIS Quarterly 34, 185-200. https://doi.org/10.2307/20721420

Nah, F.F.-H. and Davis, S. (2002), "HCI research issues in e-commerce”, Journal of Electronic Commerce Research, Vol. 3 No. 3, pp. 98-113.

Nelson, R.R., Todd, P.A. and Wixom, B.H. (2005), “Antecedents of information and system quality: an empirical examination within the context of data warehousing", Journal of Management Information Systems, Vol. 21 No. 4, pp. 199-235.

Newman, I. (1998) Qualitative-quantitative research methodology: Exploring the interactive continuum. SIU Press.

Newby, P. (2014) Research Methods for Education, second edition. Routledge.

Nusair, K., Hua, N., Ozturk, A., Butt, I., (2017). A theoretical framework of electronic word-ofmouth against the backdrop of social networking websites. Journal of Travel \& Tourism Marketing 34, 653-665. https://doi.org/10.1080/10548408.2016.1218404

Olshavsky, R.W. (1985), "Perceived quality in consumer decision making: an integrated theoretical perspective", in Jacoby, J. and Olson, J.C. (Eds), Perceived Quality: How Consumers View Stores and Merchandise, Lexington Books, Lexington, MA, pp. 3-29.

Panjakajornsak, V., (2017). A Model of Thai Consumers' Behavioral Intention: A Study of Generations $\mathrm{X}$ and Y. International Journal of e-Education, e-Business, e-Management and eLearning 7, 219-229. https://doi.org/10.17706/ijeeee.2017.7.4.219-229

Pallant, J. (2013) SPSS survival manual. McGraw-Hill Education (UK).

Park, C., Lee, T.M., (2009). Information direction, website reputation and eWOM effect: A moderating role of product type. Journal of Business Research 62, 61-67. https://doi.org/10.1016/j.jbusres.2007.11.017

Petty, R.E., Cacioppo, J.T., Goldman, R., (1981). Personal Involvement as a Determinant of Argument-Based Persuasion. Journal of Personality and Social Psychology 69, 408-419.

Petty, R.E. and Cacioppo, J.T. (1986), Communication and Persuasion: Central and Peripheral Routes to Attitude Change, Springer-Verlag, New York, NY.

Pitta, D.A. and Fowler, D. (2005), "Online consumer communities and their value to new product developers", Journal of Product \& Brand Management, Vol. 14 No. 5, pp. 283-91. 
Petty, R.E., Priester, J., Brinol, P. (2002) Mass media attitude change: implications of the elaboration likelihood model of persuasion. In: Bryant J, Zillmann D (eds) Media effects: advances in theory and research. Lawrence Erlbaum, Mahwah, pp 155-198

Polit, D. F., \& Hungler, B. P. (1998). Study guide to accompany nursing research: Principles and methods. Lippincott Williams \& Wilkins.

Pope, C., Ziebland, S., and Mays, N. (2000) Qualitative research in health care: Analysing qualitative data. BMJ, 320, pp.114-116.

Rajasekar,S., Philominathan, P., and Chinnathambi, V. (2006) Research methodology. preprint physics.

Richins, M.L., \& Root-Shaffer, T. (1988). The Role of Involvement and Opinion Leadership in Consumer Word-of-Mouth: An Implicit Model Made Explicit. Advances in Consumer Research, 15, 32-36.

Reichelt, J., Sievert, J., Jacob, F., (2014). How credibility affects eWOM reading: The influences of expertise, trustworthiness, and similarity on utilitarian and social functions. Journal of Marketing Communications 20, 65-81. https://doi.org/10.1080/13527266.2013.797758

Reza Jalilvand, M., Samiei, N., (2012). The effect of electronic word of mouth on brand image and purchase intention: An empirical study in the automobile industry in Iran. Marketing Intelligence \& Planning 30, 460-476. https://doi.org/10.1108/02634501211231946

Rogers, EM. (1983) Diffusion of innovations. Collier MacMillan Publishers, New York

Rowley, J. (2001), “Remodelling marketing communications in an internet environment”, Internet Research, Vol. 11 No. 3, pp. 203-12.

Sekaran, U. (2000). Research methods for business: A skill-building approach. John Wiley \& Sons Sandberg, J. (2004). The Rhetoric of Positivism versus interpretivism: A Personal View. MIS Quarterly, 28(1), pp. iii - xii/March

Sasmita, J., Mohd Suki, N., (2015). Young consumers' insights on brand equity: Effects of brand association, brand loyalty, brand awareness, and brand image. International Journal of Retail \& Distribution Management 43, 276-292. https://doi.org/10.1108/IJRDM-02-2014-0024

Saunders, M.N.K., Lewis, P. and Thornhill, A. (2012) Research methods for business students (6th edition). 6th edn. Harlow, England: Financial Times Prentice Hall.

Schellekens, G., P. Verlegh, and A. Smidts. (2010). "Language Abstraction in Word of Mouth." Journal of Consumer Research 37: 207-223.

Scriven, M. (1991) 'Pros and cons about goal-free evaluation', Evaluation Practice, 12(1), pp.5576. 
Shah, H., Aziz, A., Jaffari, A. R., Waris, S., Ejaz, W., Fatima, M. and Sherazi., K. (2012), The Impact of Brands on Consumer Purchase Intentions, Asian Journal of Business Management 4(2): 105-110

Sia, C.L., Tan, B. and Wei, K. (1999), "Can a GSS stimulate group polarization? An empirical study”, IEEE Transactions on Systems, Man and Cybernetics, Vol. 29 No. 2, pp. 227-237.

Strauss, A., and Corbin, J. (1998) Basics of qualitative research (2nd ed.). Newbury Park, CA: Sage. Sullivan, C. (1999), "Marketing the web in other media”, Editor \& Publisher, Vol. 132 No. 9, p. 30.

Tashakkori, A. and Teddlie, C. (2003). Handbook of Mixed Methods in Social \& Behavioral Research. Thousand Oaks: Sage.

Tien, D.H., Amaya Rivas, A.A., Liao, Y.-K., (2018). Examining the influence of customer-tocustomer electronic word-of-mouth on purchase intention in social networking sites. Asia Pacific Management Review. https://doi.org/10.1016/j.apmrv.2018.06.003

Teng, S., Khong, K.W., Chong, A.Y.L., Lin, B., (2017). Persuasive Electronic Word-of-Mouth Messages in Social Media. Journal of Computer Information Systems 57, 76-88. https://doi.org/10.1080/08874417.2016.1181501

Thomas, D. R. (2006) 'A general inductive approach for analysing qualitative evaluation data', American journal of evaluation, 27(2), pp. 237-246.

Van der Heijden, H., Verhagen, T., and Creemers, M., (2003). Understanding online purchase intentions: contributions from technology and trust perspectives. European Journal of Information Systems, 12 (1), 41-48.

Van T.E., and Hundley, V. (2001) 'The importance of pilot studies', Social research update, (35), pp. $1-4$.

Wathen, C.N., Burkell, J., (2002). Believe it or not: Factors influencing credibility on the Web. Journal of the American Society for Information Science and Technology 53, 134-144. https://doi.org/10.1002/asi.10016

Wang, Y., Rodgers, S., (2011). Electronic Word of Mouth and Consumer Generated Content: From Concept to Application. pp. 212-231. https://doi.org/10.4018/978-1-60566-792-8.ch011

Willemsen, L.M., Neijens, P.C., Bronner, F., (2012). The Ironic Effect of Source Identification on the Perceived Credibility of Online Product Reviewers: The Ironic Effect of Source Identification. Journal of Computer-Mediated Communication 18, 16-31. https://doi.org/10.1111/j.1083-6101.2012.01598.x

Wu, P.C., Wang, Y.-C., (2011). The influences of electronic word-of-mouth message appeal and message source credibility on brand attitude. Asia Pacific Journal of Marketing and Logistics 23, 448-472. https://doi.org/10.1108/13555851111165020 
Yoo, K. H., \& Gretzel, U. (2008). What motivates consumers to write online travel reviews? Information Technology \& Tourism, 10, 283-295.

\section{Appendix A: Questionnaire}

Section 1: General Information

1.Gender: Male, Female

2. Age: $18-22,23-27,28-32,33-37$, more than 37

3. Education: Diplomat, Bachelor, Master, Doctoral

4. Status: Single, Married, Divorce

5. Monthly Income: Less than 15,000 THB, 15,000-25,000 THB, 25,00135,000, 35,001-50,000 THB, More than 50,001 THB

Section 2: User background Information

2.1 Have you ever read online reviews, blogs, web board, social media posts or online communities before you make a purchase product/service?

Yes/no

2.2 If Yes, which type of channel you commonly use to read online review and comment? (you can select more than 1 answer)

- Blog (ex. Personal blog, Commercial blog)

- Web board (ex. Pantip, Reddit,)

- Review Site (ex.Tripadvisor, Wongnai)

- Facebook (ex. Influencer page, experience from user)

- YouTube (ex. YouTube channel, video by users)

- Instagram (ex. Commercial post, experience from user)

2.3 How many times you spend on reading online review before you make purchase? (by average) 
1-2 times

3-4 times

5-6 times

More than 6 times

2.4 How long you usually spend time on reading online review?

1-15 minutes

15-30 minutes

30-45 minutes

45-60 minutes

more than 60 minutes

2.5 Why do you choose to read online review more than other types of sources?

- Credibility/Trustworthy

- Convenience

- Accuracy/Precision

- Variety of Information

Section 3: Source credibility (rating scale)

3.1 The level of expertise/professional in the reviewer makes me have more trust on the review

3.2 Attitude/Opinion of information sender affects the source credibility

3.3 The more popular and well-known the website is, the more credible it is

3.4 The amount of information provided in review makes it be more credible

Section 4: Source style (rating scale)

4.1 Visual information (ex. photo, video) of the source is the important element that makes the review more interesting

4.2 Website attributes of the review (ex. Outline, Colors, Pattern, Style) make the review more attractive and trustworthy 
4.3 Language style used in the review (ex.formal/informal) is the element that affects the credibility of that review

4.4 Information sidedness (ex. positive/negative) has an impact on source credibility

Section 5: Source Homophily (rating scale)

5.1 I tend to be open-minded and accept the information that comes from a reviewer with similar characteristic as me (ex. age, education level, occupation) 5.2 I receive more credible information from reviewer that share similar characteristic with me

5.3 When I search for product/service information online, I prefer it from the source that has similar attitude and behaviour

Section 6: Argument Quality (rating scale)

6.1 Relevance of information is the factor that affects the trustworthiness of that review

6.2 Current and up-to-date information tend to make me have more trust on that review

6.3 Accuracy/validity of information makes me have more trust on that review

6.4 The depth of information on every aspect affects the credibility of that review

Section 7: eWOM credibility and information adoption (rating scale)

7.1 I strongly recommend others to adopt online review and eWOM as it has more credibility than other type of sources

7.2 I tend to adopt eWOM for finding information in my next purchase decision

Section 8: eWOM credibility and purchase intention (rating scale)

8.1 Credibility of online source affect your purchase decision towards product/service 
8.2 After I read credible and trustworthy online review, I tend to develop greater purchase intention toward that product/service

\section{Appendix B: Statistic Results}

\section{Descriptive Statistics}

\begin{tabular}{|c|c|c|c|c|c|}
\hline \multicolumn{6}{|c|}{ Descriptive Statistics } \\
\hline & $\mathrm{N}$ & Minimum & Maximum & Mean & $\begin{array}{c}\text { Std. } \\
\text { Deviation }\end{array}$ \\
\hline SC1 & 230 & 1 & 5 & 4.16 & .963 \\
\hline SC2 & 230 & 1 & 5 & 3.85 & .957 \\
\hline SC3 & 230 & 1 & 5 & 3.95 & .977 \\
\hline SC4 & 230 & 1 & 5 & 3.96 & 1.075 \\
\hline SS1 & 230 & 1 & 5 & 4.25 & 1.022 \\
\hline SS2 & 230 & 1 & 5 & 3.85 & .969 \\
\hline SS3 & 230 & 1 & 5 & 3.65 & 1.086 \\
\hline SS4 & 230 & 1 & 5 & 3.85 & 1.010 \\
\hline $\mathrm{SH} 1$ & 230 & 1 & 5 & 3.81 & 1.113 \\
\hline $\mathrm{SH} 2$ & 230 & 1 & 5 & 3.55 & .982 \\
\hline $\mathrm{SH} 3$ & 230 & 1 & 5 & 3.58 & 1.049 \\
\hline AQ1 & 230 & 1 & 5 & 4.03 & 1.004 \\
\hline AQ2 & 230 & 1 & 5 & 4.07 & .932 \\
\hline AQ3 & 230 & 1 & 5 & 4.20 & .898 \\
\hline AQ4 & 230 & 1 & 5 & 4.27 & .870 \\
\hline $\mathrm{PI} 1$ & 230 & 1 & 5 & 4.13 & 1.011 \\
\hline $\mathrm{PI} 2$ & 230 & 1 & 6 & 4.02 & .913 \\
\hline PA1 & 230 & 1 & 5 & 3.76 & .945 \\
\hline $\mathrm{PA} 2$ & 230 & 1 & 5 & 3.76 & 1.054 \\
\hline Valid N (listwise) & 230 & & & & \\
\hline
\end{tabular}


Reliability Statistics

\begin{tabular}{|c|c|c|c|}
\hline \multicolumn{2}{|c|}{ Reliability Statistics } & \multicolumn{2}{|c|}{ Reliability Statistics } \\
\hline $\begin{array}{l}\text { Cronbach's } \\
\text { Alpha }\end{array}$ & $\mathrm{N}$ of Items & $\begin{array}{l}\text { Cronbach's } \\
\text { Alpha }\end{array}$ & $\mathrm{N}$ of Items \\
\hline .740 & 4 & .766 & 4 \\
\hline
\end{tabular}

\begin{tabular}{c|r}
\multicolumn{2}{c}{$\begin{array}{c}\text { Reliability Statistics } \\
\begin{array}{c}\text { Cronbach's } \\
\text { Alpha }\end{array}\end{array}$} \\
\hline .727 & N of Items \\
\hline
\end{tabular}

\section{Reliability Statistics}

Cronbach's Alpha $\mathrm{N}$ of Items

\begin{tabular}{r|r} 
Alpha & N of Items \\
\hline .798 & 4 \\
\hline
\end{tabular}

\begin{tabular}{|c|r|}
\hline $\begin{array}{l}\text { Reliability Statistics } \\
\text { Cronbach's } \\
\text { Alpha }\end{array}$ & N of Items \\
\hline .742 & 2 \\
\hline
\end{tabular}

\section{Reliability Statistics}

Cronbach's Alpha $\mathrm{N}$ of Items .756 2 
Factor Analysis

38 


\section{Communalities}

\begin{tabular}{l|l|r} 
& Initial & Extraction \\
\hline SC1 & 1.000 & .598 \\
\hline SC2 & 1.000 & .563 \\
\hline SC3 & 1.000 & .586 \\
\hline SC4 & 1.000 & .549 \\
\hline SS1 & 1.000 & .649 \\
\hline SS2 & 1.000 & .571 \\
\hline SS3 & 1.000 & .399 \\
\hline SS4 & 1.000 & .434 \\
\hline SH1 & 1.000 & .711 \\
\hline SH2 & 1.000 & .702 \\
\hline SH3 & 1.000 & .593 \\
\hline AQ1 & 1.000 & .589 \\
\hline AQ2 & 1.000 & .673 \\
\hline AQ3 & 1.000 & .628 \\
\hline AQ4 & 1.000 & .572 \\
\hline PI1 & 1.000 & .651 \\
\hline PI2 & 1.000 & .642 \\
\hline PA1 & 1.000 & .776 \\
\hline PA2 & 1.000 & .754 \\
\hline Extract & Method & \\
\hline
\end{tabular}

Extraction Method: Principal Component Analysis.

\begin{tabular}{|c|c|c|c|c|}
\hline \multicolumn{5}{|c|}{ Rotated Component Matrix ${ }^{a}$} \\
\hline & \multicolumn{4}{|c|}{ Component } \\
\hline & 1 & 2 & 3 & 4 \\
\hline SC1 & .748 & & & \\
\hline SS1 & .709 & & & \\
\hline SC3 & .702 & & & \\
\hline $\mathrm{PI} 1$ & .648 & & & \\
\hline SS2 & .643 & & & \\
\hline SC2 & .571 & & & \\
\hline SS4 & .509 & & & \\
\hline SC4 & .486 & & & \\
\hline SS3 & .421 & & & \\
\hline AQ2 & & .778 & & \\
\hline AQ3 & & .728 & & \\
\hline AQ4 & & .672 & & \\
\hline $\mathrm{PI} 2$ & .434 & .576 & & \\
\hline AQ1 & .461 & .497 & & \\
\hline $\mathrm{SH} 2$ & & & .779 & \\
\hline $\mathrm{SH} 1$ & & & .713 & \\
\hline $\mathrm{SH} 3$ & & & .706 & \\
\hline PA2 & & & & .848 \\
\hline PA1 & & & & .779 \\
\hline \multicolumn{5}{|c|}{$\begin{array}{l}\text { Extraction Method: Principal Component Analysis. } \\
\text { Rotation Method: Varimax with Kaiser } \\
\text { Normalization. }^{\text {a }}\end{array}$} \\
\hline \multicolumn{5}{|c|}{ a. Rotation converged in 6 iterations. } \\
\hline
\end{tabular}

\begin{tabular}{|llr|}
\hline \multicolumn{3}{|c|}{ KMO and Bartlett's Test } \\
\hline $\begin{array}{l}\text { Kaiser-Meyer-Olkin Measure of Sampling } \\
\text { Adequacy. }\end{array}$ & .925 \\
\hline $\begin{array}{l}\text { Bartlett's Test of } \\
\text { Sphericity }\end{array}$ & Approx. Chi-Square & 1987.292 \\
\cline { 2 - 3 } & df & 171 \\
\cline { 2 - 3 } & Sig. & .000 \\
\hline
\end{tabular}

\section{Regression (Linear\#1)}




\begin{tabular}{|c|c|c|c|c|c|c|c|c|c|}
\hline \multicolumn{10}{|c|}{ Model Summary } \\
\hline \multirow[b]{2}{*}{ Model } & \multirow[b]{2}{*}{$\mathrm{R}$} & \multirow[b]{2}{*}{ R Square } & \multirow[b]{2}{*}{$\begin{array}{l}\text { Adjusted R } \\
\text { Square }\end{array}$} & \multirow[b]{2}{*}{$\begin{array}{l}\text { Std. Error of } \\
\text { the Estimate }\end{array}$} & \multicolumn{5}{|c|}{ Change Statistics } \\
\hline & & & & & $\begin{array}{c}\text { R Square } \\
\text { Change }\end{array}$ & F Change & $\mathrm{df1}$ & $\mathrm{df} 2$ & Sig. F Change \\
\hline 1 & $.444^{a}$ & .197 & .193 & .80593 & .197 & 55.844 & 1 & 228 & .000 \\
\hline
\end{tabular}

\begin{tabular}{|c|c|c|c|c|c|c|}
\hline \multicolumn{7}{|c|}{ ANOVA $^{a}$} \\
\hline \multicolumn{2}{|c|}{ Model } & $\begin{array}{l}\text { Sum of } \\
\text { Squares }\end{array}$ & df & Mean Square & $\mathrm{F}$ & Sig. \\
\hline \multirow[t]{3}{*}{1} & Regression & 36.272 & 1 & 36.272 & 55.844 & $.000^{\mathrm{b}}$ \\
\hline & Residual & 148.093 & 228 & .650 & & \\
\hline & Total & 184.365 & 229 & & & \\
\hline \multicolumn{7}{|c|}{ a. Dependent Variable: PurchaseAdoption } \\
\hline
\end{tabular}

\begin{tabular}{|c|c|c|c|c|c|c|}
\hline \multicolumn{7}{|c|}{ Coefficients $^{a}$} \\
\hline \multirow{2}{*}{\multicolumn{2}{|c|}{ Model }} & \multicolumn{2}{|c|}{ Unstandardized Coefficients } & \multirow{2}{*}{$\begin{array}{c}\text { Standardized } \\
\text { Coefficients } \\
\text { Beta } \\
\end{array}$} & \multirow[b]{2}{*}{$t$} & \multirow[b]{2}{*}{ Sig. } \\
\hline & & B & Std. Error & & & \\
\hline \multirow[t]{2}{*}{1} & (Constant) & 1.333 & .329 & & 4.057 & .000 \\
\hline & eWOMcredibility & .616 & .082 & .444 & 7.473 & .000 \\
\hline
\end{tabular}

Regression (Linear \#2) 


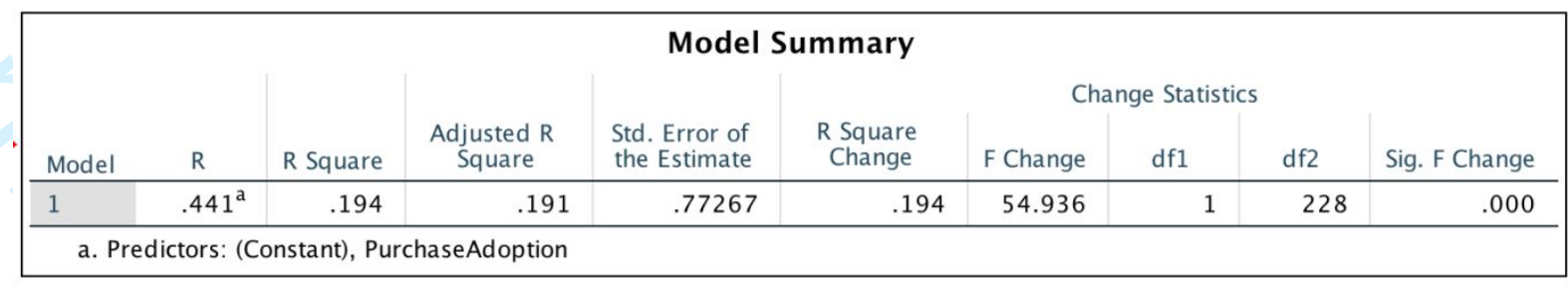

\begin{tabular}{|c|c|c|c|c|c|c|}
\hline \multicolumn{7}{|c|}{ ANOVA $^{a}$} \\
\hline \multicolumn{2}{|c|}{ Model } & $\begin{array}{l}\text { Sum of } \\
\text { Squares }\end{array}$ & $d f$ & Mean Square & $\mathrm{F}$ & Sig. \\
\hline \multirow[t]{3}{*}{1} & Regression & 32.798 & 1 & 32.798 & 54.936 & $.000^{b}$ \\
\hline & Residual & 136.121 & 228 & .597 & & \\
\hline & Total & 168.918 & 229 & & & \\
\hline
\end{tabular}

a. Dependent Variable: PurchaseIntention

b. Predictors: (Constant), PurchaseAdoption

\begin{tabular}{|c|c|c|c|c|c|c|}
\hline \multicolumn{7}{|c|}{ Coefficients $^{a}$} \\
\hline & & \multicolumn{2}{|c|}{ Unstandardized Coefficients } & \multirow{2}{*}{$\begin{array}{c}\text { Standardized } \\
\text { Coefficients } \\
\text { Beta }\end{array}$} & \multirow[b]{2}{*}{$\mathrm{t}$} & \multirow[b]{2}{*}{ Sig. } \\
\hline & & B & Std. Error & & & \\
\hline \multirow[t]{2}{*}{1} & (Constant) & 1.333 & .329 & & 4.057 & .000 \\
\hline & eWOMcredibility & .616 & .082 & .444 & 7.473 & .000 \\
\hline
\end{tabular}

\section{Regression (Multiple Regression)}




\begin{tabular}{|c|c|c|c|c|c|c|c|c|c|}
\hline \multicolumn{10}{|c|}{ Model Summary } \\
\hline \multirow[b]{2}{*}{ Model } & \multirow[b]{2}{*}{$\mathrm{R}$} & \multirow[b]{2}{*}{ R Square } & \multirow[b]{2}{*}{$\begin{array}{l}\text { Adjusted R } \\
\text { Square }\end{array}$} & \multirow[b]{2}{*}{$\begin{array}{l}\text { Std. Error of } \\
\text { the Estimate }\end{array}$} & \multicolumn{5}{|c|}{ Change Statistics } \\
\hline & & & & & $\begin{array}{c}\text { R Square } \\
\text { Change }\end{array}$ & F Change & df1 & $\mathrm{df} 2$ & Sig. F Change \\
\hline 1 & $.462^{\mathrm{a}}$ & .213 & .199 & .80295 & .213 & 15.239 & 4 & 225 & .000 \\
\hline
\end{tabular}

\begin{tabular}{|c|c|c|c|c|c|c|}
\hline \multicolumn{7}{|c|}{ ANOVA $^{a}$} \\
\hline \multicolumn{2}{|c|}{ Model } & $\begin{array}{l}\text { Sum of } \\
\text { Squares }\end{array}$ & df & Mean Square & $\mathrm{F}$ & Sig. \\
\hline \multirow[t]{3}{*}{1} & Regression & 95.635 & 4 & 23.909 & . &.$^{b}$ \\
\hline & Residual & .000 & 225 & .000 & & \\
\hline & Total & 95.635 & 229 & & & \\
\hline \multicolumn{7}{|c|}{ a. Dependent Variable: eWOMcredibility } \\
\hline \multicolumn{7}{|c|}{$\begin{array}{l}\text { b. Predictors: (Constant), ArgumentQuality, SourceHomophily, SourceCredibility, } \\
\text { SourceStyle }\end{array}$} \\
\hline
\end{tabular}

\begin{tabular}{|c|c|c|c|c|c|c|}
\hline \multicolumn{7}{|c|}{ Coefficients $^{a}$} \\
\hline & & \multicolumn{2}{|c|}{ Unstandardized Coefficients } & \multirow{2}{*}{$\begin{array}{c}\text { Standardized } \\
\text { Coefficients } \\
\text { Beta } \\
\end{array}$} & \multirow[b]{2}{*}{$\mathrm{t}$} & \multirow[b]{2}{*}{ Sig. } \\
\hline \multicolumn{2}{|c|}{ Model } & B & Std. Error & & & \\
\hline \multirow[t]{5}{*}{1} & (Constant) & $-1.998 \mathrm{E}-15$ & .000 & & .000 & 1.000 \\
\hline & SourceCredibility & .267 & .000 & .307 & 206294694 & .000 \\
\hline & SourceStyle & .267 & .000 & .323 & 210824108 & .000 \\
\hline & SourceHomophily & .200 & .000 & .261 & 227642801 & .000 \\
\hline & ArgumentQuality & .267 & .000 & .302 & 220838719 & .000 \\
\hline
\end{tabular}

a. Dependent Variable: eWOMcredibility 